\title{
Rhizobakteria Formulation Tests Phospat Indigenous Peanut to Increase P Inquiry
}

\author{
A Anidarfi ${ }^{1}, \mathrm{~N} \mathrm{Sembiring}^{2}, \mathrm{~A} \mathrm{Asman}^{3}$, L Rozaira $^{4}$ \\ Food Crop Cultivation Department, State Polytechnic of Agriculture, \\ 26271 Tanjung Pati, Limapuluh Kota, West Sumatera, Indonesia ${ }^{1,2,3,4}$
}

\{secretariat@politanipyk.ac.id\}

\begin{abstract}
The availability of soil $\mathrm{P}$ is strongly influenced by soil $\mathrm{pH}, \mathrm{P}$ will be compounded with $\mathrm{Al}$ and $\mathrm{Fe}$, in alkaline soil, $\mathrm{P}$ is compounded with $\mathrm{Ca}$, thus transforming into a form not available to the plant. Increased efficiency of $\mathrm{P}$ availability for plants can be pursued by utilizing Bacterial Pelarut Fospat (BPF) as alternative technology of bio-fertilizer (biofertilizer) The purpose of this research is to obtain Liquid biofertilizer formulation of Indigenous Platte Fluid Plungut Fungus and analysis of storage life of liquid biofertilizer that has been produced. Isolation and characterization of bacterial solvent phosphate have been carried out from rhizosphere at different altitudes. One isolate selected. Isolate A3.rh.BPF indigenous origin Baso Regency of Agam grown on liquid carrier know able liquid waste 4 levels: P1) 25\% LTC, P2) 50\% LTC, P3) 75\% LTC, and P4) $100 \%$ LTC. Observations were made on the total population of BPF for 0,4 and 8 weeks of storage. The results show that the BPF population endurance in storage for up to 8 weeks is $75 \%$ LTC (P3) with the best pH ranging from 5-6.5.
\end{abstract}

Keywords: indigenous, phosphate solubilizing, rhizobacteria, formulation test, peanut.

\section{Introduction}

Phosphorus $(\mathrm{P})$ is one of the essential macro nutrient elements play a role very important in plant growth and development particularly in the process of cell metabolism. The content of $\mathrm{P}$ in the soil in the form of available, much lower compared to other macro nutrient elements, such as Nitrogen $(N)$, Potassium $(\mathrm{K})$ and Calcium $(\mathrm{Ca})$. It is presence on the ground is actually quite abundant, but the concentration of $\mathrm{P}$ that can be absorbed by plants is thus very low because it is in a form that is not available [1].

The concentration of $\mathrm{P}$ available in soils affected by $\mathrm{pH}$ and soil type. On the soil, sour $\mathrm{P}$ bonded with Aluminium ( $\mathrm{Al}$ ) and Iron (Fe), whereas in alkaline soil $\mathrm{P}$ bonded with $\mathrm{Ca}$. The presence of the $\mathrm{P}$ fertilizer given to become inefficient, because even after the given immobilises $\mathrm{P}$ will happen to be unavailable to plants. This is caused by high retention against elements of $\mathrm{P}$, so the concentration of $\mathrm{P}$ in the soil diminished [2].

Increased efficiency of phosphate availability to plants can be attempted by utilizing solvent phosphate bacteria (BPF) as alternative technology for biological fertilizer (a biofertilizer). Biofertilizer contain microorganisms living that can facilitate the availability of nutrient elements in soil. Bacteria solvent phosphate (BPF) as a biofertilizer is a group of bacteria that can dissolve the trap surface oxide P-iron oxide compounds as Aluminium and Fe-P and Al-P 
[3]. The dissolving effects caused by the presence of the production of organic acids such as acetic acid, formic acid, lactic acid, oxalic acid, Malic acid and citric acid produced by the microbes [4]. BPF also dissolve $\mathrm{P}$ spending mechanisms with the enzyme. Soil enzymes that play a role in the process of mineralized organic $\mathrm{P}$ compounds into inorganic $\mathrm{P}$ are a group of enzymes known as phosphatase [5].

Phosphatase in soils can be derived from plant roots and microorganisms, but the amount of the more dominant is a phosphatase that is produced by microorganisms [6]. Test potential solubility of $\mathrm{P}$ by the BPF indigenous isolated from peanut rhizosphere area Baso, Agam, West Sumatera has been done by testing the adaptability and potential of the indigenous BPF dissolving re-inoculation in peanut crops. This research was carried out with the aim to test the potential of media carrier BPF and effectiveness against an increase in the production of peanuts.

Yelti, Zul dan Febrianti (2014) [17] reported that the use of liquid tofu waste as a carrier medium BPF at room temperature can sustain populations up to $60 \mathrm{hr}$ of storage, better than liquid pikovskaya carrying media.

\section{Method}

Previous research has obtained isolate bacterial isolates of phospat rhizosfir indegenous A3.rh.BPF peanuts which are most effective in dissolving $\mathrm{P}$ and can increase the number of pods and weight of 100 seeds of peanut. (Anidarfi, Ngakumalem dan Asman 2015).

This research was carried out in the laboratory of Payakumbuh State Polytechnic of Agriculture, from April to July 2017. BPF a tested is a bacterial isolate is A3. rh. rhizosphere indigenous BPF peanut plants sourced Baso, Agam Regency, which was grown on media carrier liquid formulation consists of 4 levels percentage of Tahu liquid waste (LTC) are given a molasses $2 \%$ on water distillation and then autoclave for 15 minutes at a temperature of $121^{\circ}$ C. with: P1) 25\% LTC, P2) 50\% LTC, P3) 75\% LTC, and P4) 100\% LTC.

Inoculant in incubation over 0 week 4 weeks and 8 weeks. The variables observed in this study are: (1) the resilience of the population on LTC storage media; (2) liquid media formulation $\mathrm{pH}$ levels are measured using a $\mathrm{pH}$ meter on each period of storage; Test of viability by calculating the total bacterial populations using the method of Total Plate Count (TPC). As many as $1 \mathrm{ml}$ inoculum BPF of formulation media of any treatment put into $9 \mathrm{ml}$ of water sterile to create a dilution series $10^{1}-10^{9}$. As much as $0.1 \mathrm{ml}$ suspension of dilution of $10^{7}, 10^{8}$ and $10^{9}$ in the eyedropper into petri which already contains medium dense Pikovskaya and incubated during $3 \times 24$ hours at room temperature.

Colonies of bacteria that grow are observed and calculated the total population (CFU) by using the methods of the bowls so that (Plate Counting) [7], the influence of BPF against peanut production include: $\mathrm{A} 1=$ unannounced $\mathrm{BPF}, \mathrm{B} 2=$ with the awarding of the $\mathrm{PBF}\left(10^{6} \mathrm{CFU} \cdot \mathrm{ml}^{-}\right.$ $\left.{ }^{1}\right)$. For the volume of each isolate $\mathrm{B} 1=5 \mathrm{ml}, 10 \mathrm{ml}=\mathrm{B} 2$ and $\mathrm{B} 3=15 \mathrm{ml}$. Data and observations are analysed to compare between different treatment is continued with the real test of Duncan at $5 \%$ and $1 \%$ level.

\section{Result and Discussion}

Characteristics of BPF. BPF indigenous Isolates rhizospheres beans tested, has the following characteristics in Table 1. 
Table I. Characteristics of BPF Indigenous Regional Peanut Rhizosfir Baso, Agam

\begin{tabular}{ll}
\multicolumn{1}{c}{ Regency } & \\
\hline \multicolumn{1}{c}{ The Observation Parameters Required } & Karakteristik Isolat BPF \\
\hline Code isolates & A3.rh.BPF \\
\hline The diameter of the colony $(\mathrm{mm})$ & 4.87 \\
\hline The diameter of the holozone $(\mathrm{mm})$ & 11.60 \\
\hline The ratio of holozone & 1.41 \\
\hline Total Population $\left(\mathrm{CFU}^{-\mathrm{ml}^{-1}}\right)$ & $5.77 \times 10^{6}$ \\
\hline P-dissolved $\left(\mathrm{ppm} \cdot\right.$ days $\left.^{-1}\right)$ & 5.47 \\
\hline
\end{tabular}

Growth of MPF on medium Pikovskaya produces clear halozone around the colony after 6 days of growth. Halozone formed clear ratio can reach 1.41 compared the diameter of the colonies. Solvent phosphate bacteria contained in a solid carrier media is able to dissolve a bound $\mathrm{P}$ is characterized by the ability of the BPF in generating a clear zone around the colony[7]. To assure that the BPF really thrive in liquid biofertilizer produced, then at each counting of the population of the BPF observed colonies of BPF seems. In Figure 1 presents the documented colonies of BPF that grow in a liquid biofertilizer is characterized by the formation of a clear zone around colonies when grown on solid media Pikovkaya.

The ability of the BPF in the dissolving of $\mathrm{P}$ elements that are bound to other elements characterized by the presence of positive reactions in medium Pikovskaya, i.e. the formation of a clear zone around the bacterial colonies. The establishment of clear zone indicates that the bacteria are able to produce extracellular enzymes or acid phosphatase that is organic. Based on a test of the ability of dissolving $\mathrm{P}$, isolates A3.rh.BPF is able to dissolve $\mathrm{P}_{\text {of }} \mathrm{Ca}_{3} \mathrm{PO}_{4}$ up to 5.47 ppm $\mathrm{P}$ each day. Testing the dissolving of $\mathrm{P}$ in the form of $\mathrm{FePO}_{4}$ and $\mathrm{AlPO}_{4}$, isolates $\mathrm{BPF} \mathrm{A} 3$. rh. BPF, is not capable of doing the dissolving of $\mathrm{P}$ as shown in Figure 1.
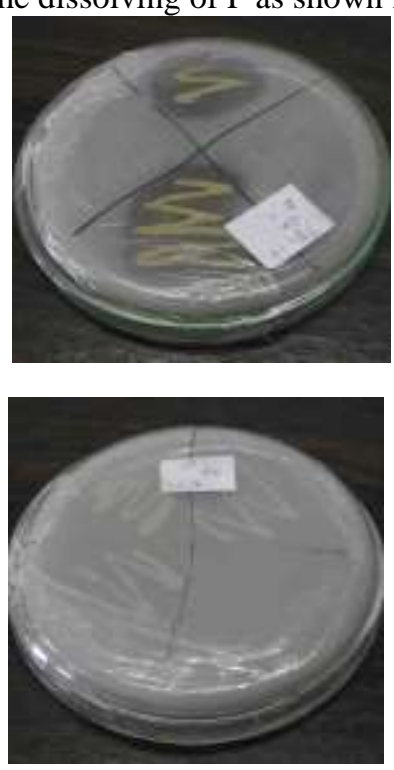


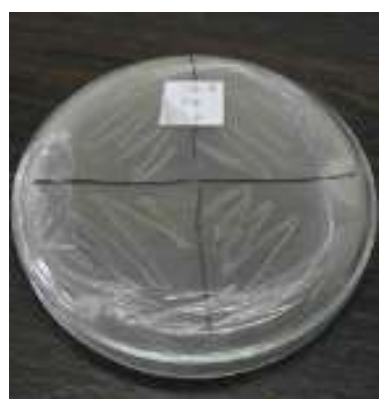

Figure 1. Dissolving activity $\mathrm{P}$ on media Pikovskaya a). $\mathrm{Ca}_{3} \mathrm{PO}_{4}$; b) $\mathrm{FePO}_{4}$ and c) $\mathrm{AlPO}_{4}$

Tabel 2. Population Growth And Resilience of BPF on Media Formulations Ltc (Cfu/Ml)

\begin{tabular}{cccc}
\hline Media & \multicolumn{3}{c}{ Storage Period (weeks) } \\
\hline Treatment & $\mathbf{0}$ & $\mathbf{4}$ & $\mathbf{8}$ \\
\hline P1 & $2.23 \times 10^{6}$ & $7.64 \times 10^{9}$ & $1.92 \times 10^{5}$ \\
\hline P2 & $2.31 \times 10^{6}$ & $3.45 \times 10^{10}$ & $5.21 \times 10^{6}$ \\
\hline P3 & $2.46 \times 10^{6}$ & $6.21 \times 10^{10}$ & $3.66 \times 10^{8}$ \\
\hline P4 & $3.14 \times 10^{6}$ & $4.82 \times 10^{11}$ & $2.93 \times 10^{6}$ \\
\hline
\end{tabular}

The population of BPF- The population of bacteria on the LTC during storage media experienced a decline until the storage is 8 weeks. The results are still far lower than have a population of bacteria Pseudomonas striata to $10^{9} \mathrm{CFU} \cdot \mathrm{ml}^{-1}$ for 24 months storage using molten Pikovskaya formula. If the review of the formula used, it can be concluded that the formula the best LTC as a storage medium is a medium formulation BPF P3 which is characterized by the growth of the population of the BPF high enough up to 8 weeks storage.

The abundance of carbon sources contained in the formula liquid biofertilizer cause higher bacterial populations up to 8 week period of storage. The source of the carbon contained in the formulation, a major factor as nutrients for bacterial growth in liquid biofertilizer production, so the bacteria are able to survive in long periods [8]. Difference bacterial populations on the third caused by nutritional formulations which vary in each formulation. However, during the storage of the population decline occurring bacteria.

Population decline is caused by the presence of competition between bacteria in obtaining nutrients for its growth. According to the Rev. [9], the difference in population of bacteria caused by the growing capabilities of each type of bacteria. The bacteria have the ability to grow and adapt in accordance with the conditions of its growth, as well as being able to utilize carbon as source of nutrients contained in the BPF formula liquid biofertilizer. Based on a formula that is used, that the quality of liquid biofertilizer depends heavily on the effectiveness of the live cell count and bacteria contained in the liquid biofertilizer [10].

The process of dissolving the element $\mathrm{P}$ is very dependent on environmental conditions such as temperature, moisture, $\mathrm{pH}$ and nutrients during growth. In addition to being influenced by temperature, bacteria growth is also affected by the degree of acidity [11].

The $\mathrm{pH}$ levels of BPF- The growth of bacteria in liquid media-also affected by the $\mathrm{pH}$. The optimum $\mathrm{pH}$ range for growth of bacteria is 6.5-7.5. PH measurement of liquid media is done during storage at room temperature. Data obtained are shown in Table 3. 
Tabel 3. PH of LTC media observation

\begin{tabular}{cccc}
\hline Media & \multicolumn{3}{c}{ Strorage Period (weeks) } \\
\hline Trearment & $\mathbf{0}$ & $\mathbf{4}$ & $\mathbf{8}$ \\
\hline P1 & $6,79 \pm 0,11$ & $5,68 \pm 0,57$ & $5,01 \pm 0,05$ \\
\hline P2 & $6,29 \pm 0,17$ & $5,42 \pm 0,24$ & $5,13 \pm 0,32$ \\
\hline P3 & $6,12 \pm 0,76$ & $5,35 \pm 0,68$ & $4,91 \pm 0,41$ \\
\hline P4 & $6,07 \pm 0,63$ & $5,39 \pm 0,23$ & $4,34 \pm 0,08$ \\
\hline
\end{tabular}

The influence of $\mathrm{pH}$ against the growth of bacteria related to the activity of enzymes to catalyze reactions that are related to the growth of bacteria. If the $\mathrm{pH}$ is not optimum bacterial growth will result in a disruption of bacterial growth [9]. Based on the optimum $\mathrm{pH}$ for the growth of bacteria, the data shows that there is an optimum $\mathrm{pH}$ range at liquid biofertilizer stored at room temperature with liquid waste know the formula to save 0 Sunday that range 6.12-6,79, 5.35-5.68 4 weeks and 8 weeks 4.34-5.01. However, if seen from the media used, the formula is obtained that the $\mathrm{pH}$ of the media LTC experience a decrease to 8-week period of storage.

The highest decrease in $\mathrm{pH}$ range occurs on the media formulation $\mathrm{P} 3$ and $\mathrm{P} 4$ are reaching a $\mathrm{pH}$ range of 4 . Even so, the $\mathrm{pH}$ of the medium $\mathrm{pH}$ is in the range of LTC that are common to the growth of bacteria, namely ranges 4-9 and still support the viability of the bacteria for up to 8 weeks storage.

Low $\mathrm{pH}$ values on liquid biofertilizer will affect the growth of bacteria. The bacteria are not able to live in the acidic $\mathrm{pH}$ will experience a phase of death and causes the low population of bacteria during storage. According to [12], pH changes in activity caused by the liquid biofertilizer BPF in dissolving the source P. where there is a change of carbon compounds produce some organic acids such as citric acid, malic and gluconate [13].

The formation of organic acids which may lead to the occurrence of a decrease in $\mathrm{pH}$ and affect the activity of the bacterial cell metabolism [7]. The absorption of glucose in aqueous media formulas and the possibility of LTC compound bioconversion acid-organic acids, led to a decrease in $\mathrm{pH}, \mathrm{pH}$ of around 6,79-4.34 storage up to 8 weeks. [14] noted that the drop in $\mathrm{pH}$ is one of the causes of the occurrence of $\mathrm{Ca}-\mathrm{P}$ dissolving into orthophosphate.

Dissolving mechanism $\mathrm{P}$ pH changes due to involve the synthesis of organic compounds which are released into the formula, the reduction of oxidation reactions [4]. The dissolving of $\mathrm{P}$ in the media through the possibility of a decrease in LTC $\mathrm{pH}$, with the value of the correlation between the increase in the dissolving of $\mathrm{P}$ with a decrease in the $\mathrm{pH}$ of the media LTC until 8 weeks storage. [4][4] States that the $\mathrm{pH}$ affect enzyme activity by altering solubility of substrate. A decrease in the $\mathrm{pH}$ of the liquid biofertilizer for storage 8 weeks also correlated with bacterial population. The low $\mathrm{pH}$ value caused by the activity of BPF in the form of metabolites produce acid-organic acids and enzymes phosphomonoesters (PME).

\section{Conclusion}

At 0,4 and 8 weeks storage there was a decrease in BPF population and carrier $\mathrm{pH}$. The decrease in $\mathrm{pH}$ of the liquid waste carrier medium during storage is positively correlated with the bacterial population. The best LTC media composition against BPF population endurance in up to 8 weeks storage is 75\% LTC, $2 \%$ Molase in Air Distillation (P3) BPF Population. While the best $\mathrm{pH}$ for LTC media is between 5-6.5. 


\section{Acknowledgment}

This paper was supported and funded by DRPM RISTEK DIKTI and P3M of Payakumbuh State Polytechnic of Agriculture, Indonesia.

\section{References}

[1] A. Paytan and K. McLaughlin, "The oceanic phosphorus cycle," Chem. Rev., vol. 107, no. 2, pp. 563-576, 2007.

[2] W. A. Dick, L. Cheng, and P. Wang, "Soil acid and alkaline phosphatase activity as pH adjustment indicators," Soil Biol. Biochem., vol. 32, no. 13, pp. 1915-1919, 2000.

[3] M. Rathi and N. Gaur, "Phosphate solubilizing bacteria as biofertilizer and its applications," J. Pharm. Res., vol. 1010, no. 3, pp. 146-148, 2016.

[4] H. Fankem, D. Nwaga, a Deubel, L. Dieng, W. Merbach, and F. X. Etoa, "Occurrence and functioning of phosphate solubilizing microorganisms from oil palm tree (Elaeis guineensis) rhizosphere in Cameroon," African J. Biotechnol., vol. 5, no. 24, pp. 2450 2460, 2006.

[5] B. Sarapatka, "Phosphatase activity of eutric cambisols (Uppland, Sweden) in relation to soil properties and farming systems," Sci. Agric. Bohem., vol. 33, no. 1, pp. 18-24, 2002.

[6] E. J. Joner and A. Johansen, "Phosphatase activity of external hyphae of two arbuscular mycorrhizal fungi," Mycol. Res., vol. 104, no. 1, pp. 81-86, 2000.

[7] D. M. Sylvia, J. J. Fuhrmann, P. G. Hartel, D. A. Zuberer, and A. M. Cupples, Principles and applications of soil microbiology, vol. 34, no. 2. 2005.

[8] L. A. Cuevas, J. K. Egge, T. F. Thingstad, and B. Töpper, "Organic carbon and mineral nutrient limitation of oxygen consumption, bacterial growth and efficiency in the Norwegian Sea," Polar Biol., vol. 34, no. 6, pp. 871-882, 2011.

[9] S. Antonius and D. Agustiyani, "Pengaruh Pupuk Organik Hayati Yang Mengandung Mikroba Bermanfaat Terhadap Pertumbuhan Dan Hasil Panen Tanaman Semangka Serta Sifat Biokimia Tanahnya Pada Percobaan Lapangan Di Malinau-Kalimantan Timur," J. Berk. Penelit. hayati, vol. 16, pp. 203-206, 2011.

[10] D. A. Setyorini D, R Saraswati dan E.K Anwar dalam R.D.M. Simanungkalit, R. S. Suriadikarta, and dan W. H. Diah Setyorini, Pupuk organik dan pupuk hayati. 2006.

[11] J. Fan, T. Onal Okyay, and D. Frigi Rodrigues, "The synergism of temperature, $\mathrm{pH}$ and growth phases on heavy metal biosorption by two environmental isolates," J. Hazard. Mater., vol. 279, pp. 236-243, 2014.

[12] S. F. Lim and S. U. Matu, "Utilization of agro-wastes to produce biofertilizer," Int. J. Energy Environ. Eng., vol. 6, no. 1, pp. 31-35, 2015.

[13] K. V. B. R. Tilak et al., "Diversity of plant growth and soil health supporting bacteria," Curr. Sci., vol. 89, no. 1, pp. 136-150, 2005.

[14] C. Altomare, W. A. Norvell, T. Björkman, and G. E. Harman, "Solubilization of phosphates and micronutrients by the plant-growth- promoting and biocontrol fungus Trichoderma harzianum Rifai 1295-22," Appl. Environ. Microbiol., vol. 65, no. 7, pp. 2926-2933, 1999. 